\title{
ENERGY STORAGE SYSTEM POLICIES: WAY FORWARD AND OPPORTUNITIES FOR EMERGING ECONOMIES
}

\author{
Suleiman B Sani ${ }^{1}$, Pragash Celvakumaran ${ }^{1}$, Vigna K. Ramachandaramurthy ${ }^{1}$, Sara Walker ${ }^{2}$, Bakhtiar Alrazi ${ }^{3}$, Yong Jia \\ Ying $^{1}$, Nofri Yenita Dahlan ${ }^{4}$, Mohd Hazwan Abdul Rahman ${ }^{5}$ \\ ${ }^{I}$ Institute of Power Engineering, Department of Electrical Power Engineering, College of Engineering, Universiti Tenaga Nasional, Jalan IKRAM- \\ UNITEN, 43000, Kajang, Selangor, Malaysia \\ ${ }^{2}$ Newcastle University, Newcastle upon Tyne NE1 7RU, United Kingdom \\ ${ }^{3}$ College of Business Management and Accounting, Universiti Tenaga Nasional, 26700 Muadzam Shah, Pahang, Malaysia \\ ${ }^{4}$ UiTM Solar Energy Research Center, Universiti Teknologi MARA (UiTM) Shah Alam, Selangor Malaysia \\ ${ }^{5}$ Energy Commission, Precinct 2, 62100, Putrajaya, Malaysia
}

Corresponding author

Email address: suleimanbsani@gmail.com (Suleiman Bala Sani)

\begin{abstract}
The need to reduce greenhouse gas emissions has catalysed the rapid growth of renewable energy worldwide. However, the intermittent nature of renewable energy requires the support of energy storage systems (ESS) to provide ancillary services and save excess energy for use at a later time. ESS policies have been proposed in some countries to support the renewable energy integration and grid stability. These policies are mostly concentrated around battery storage system, which is considered to be the fastest growing energy storage technology due to its efficiency, flexibility and rapidly decreasing cost. ESS policies are primarily found in regions with highly developed economies, that have advanced knowledge and expertise in the sector. This paper provides a comprehensive review of ESS policies worldwide, identifying the different goals, objectives and the expected outcomes. It discusses the benefits of having such policies, the impact they have and opportunities they have created in the energy sector. Some of the countries that have been identified to have mature ESS policies are United States of America, United Kingdom, Germany, South Korea, Japan, China and Australia. These countries have the most advanced storage technologies and are constantly undertaking research, development and demonstration (RD\&D) projects sponsored by the industry and government. ESS policies mostly promote energy storage by providing incentives, soft loans, targets and a level playing field. Nevertheless, a relatively small number of countries around the world have implemented the ESS policies. It is hoped that other countries especially in the emerging economies will learn from their experiences and adopt the policies to assist local entities that want to drive change in their community.
\end{abstract}

Keywords: Battery Energy Storage System, Energy Storage System, Policy, Renewable Energy

\section{Introduction}

Energy storage systems (ESS) have been around for a long time with the earliest and most popular form being the Pumped Hydro Storage [1]. Other forms of ESS are compressed air, flywheel, super-capacitor and battery. All these ESS technologies have their advantages and disadvantages and are used according to the application of the ESS and some other considerations such as cost, location and whether high energy or high power functions are needed [2]. In order to reduce the carbon output from traditional fossil fuel powered power plants and vehicles, several countries have promoted the use of renewable energy sources such as solar PV, wind and electrical vehicle (EV). Renewable energy sources are intermittent in nature and as such need ESS to provide ancillary services and to stabilize the output or to 
store electricity for use at a later time when required. ESS technologies are also used in the power sector for grid stability, power back up and energy arbitrage [3]. These functions contribute in stabilising the power sector and hence save a lot of money for the sector.

Many energy related policies, such as renewable energy policies and market reforms have been implemented in many parts of the world. However, ESS policies have only recently started to be adopted and promoted in some countries. It is only with ESS policies that barriers blocking the development of ESS can be eliminated to ensure they can one day become a norm in our households, businesses and even the grid. Also, ESS policies play a major role in the development of green technologies which are good for low carbon emissions. ESS policies have not been covered extensively in academic journals. Hence, the information about policies in this paper are mostly acquired from government websites related to policy making, working papers, conference proceedings and energy agencies. Mark Winfield and team examined the niche level development of new ESS technologies in the European Union, Canada and the United States in [4]. They employed a multilevel perspective approach that examined development of new ESS technologies as an encounter between existing regulatory, technological and social regimes. The authors in [5] studied the changes needed in regulation of electricity systems to accommodate ESS. Services provided by ESS were identified and the two relevant 'arenas' for services related to storage were pointed out. These were (i) avoiding distribution/transmission for transport of energy and (ii) selling and buying energy at different times. In [6] , Byuk Keun Jo and team evaluated the impact of an incentive scheme for behind the meter ESS called electricity charge discount program in South Korea. Based on a case study that was carried out to study the impact of the program, the profitability of behind the meter ESS showed tremendous improvement. The regulatory and market environment for the provision of ancillary services in the US was explored in [7]. The full potential of ESS in a smart grid was realised, by reconceptualising ESS as an asset class in a central role in the future structure of the grid and power markets in [8]. In [9], a typology was developed to analyse different technologies and how they require different types of capabilities for industry localisation in emerging economies. This was done to serve as a guideline for policy design and technology selection in different countries.

In this paper, a comprehensive review of existing ESS policy worldwide is presented and samples from different countries are discussed with emphasis on battery ESS. Considerations to be made before implementation of such policies, barriers and drivers are also discussed. The highlights of this paper are (i) prominent tools and facilitators that are considered when making ESS policy to act as a guide for creating effective policy, (ii) trends in ESS policy worldwide, (iii) similarities in policy, which in most cases encourages incentives, soft loans, targets and competition, and (iv) impacts and opportunities attached to ESS policy for emerging economies are presented.

This paper is organised into seven sections. Section 2 discusses the prominent tools and facilitators of an ESS policy. Section 3 highlights the ESS policies around the world with sample policies from some of the countries that have adopted it. Section 4 evaluates the impact of ESS policies on countries that have implemented it. Section 5 looks into the opportunities of ESS policy for emerging economies. General discussion about ESS policies is provided in Section 6 while the conclusion is presented in Section 7.

\section{Prominent Tools and Facilitators of an Energy Storage Policy}

In general, policies are designed to establish boundaries and provide regulatory guidelines. According to the Energy Storage Association (ESA), the policy tools fall under three categories which are value, access and competition [10]. The policy should increase the value of ESS by establishing deployment targets, incentive programs and creating markets for it. The policy should establish access to ESS by reducing limitations for grid interconnection, adjusting codes and standards and promoting multiple use functionality of storage. The drivers of an ESS policy are illustrated in Figure 1. The prime objectives of an ESS policy are:

- To inaugurate the best practices that will sustain the positive economic impact of energy storage development on consumers and local communities. 
- To promote and encourage ESS implementations among ratepayers.

- To develop fair and competitive markets for the adaptation of ESS technologies.

- To ensure that regulatory policies are able to reflect the values provided by ESS projects.

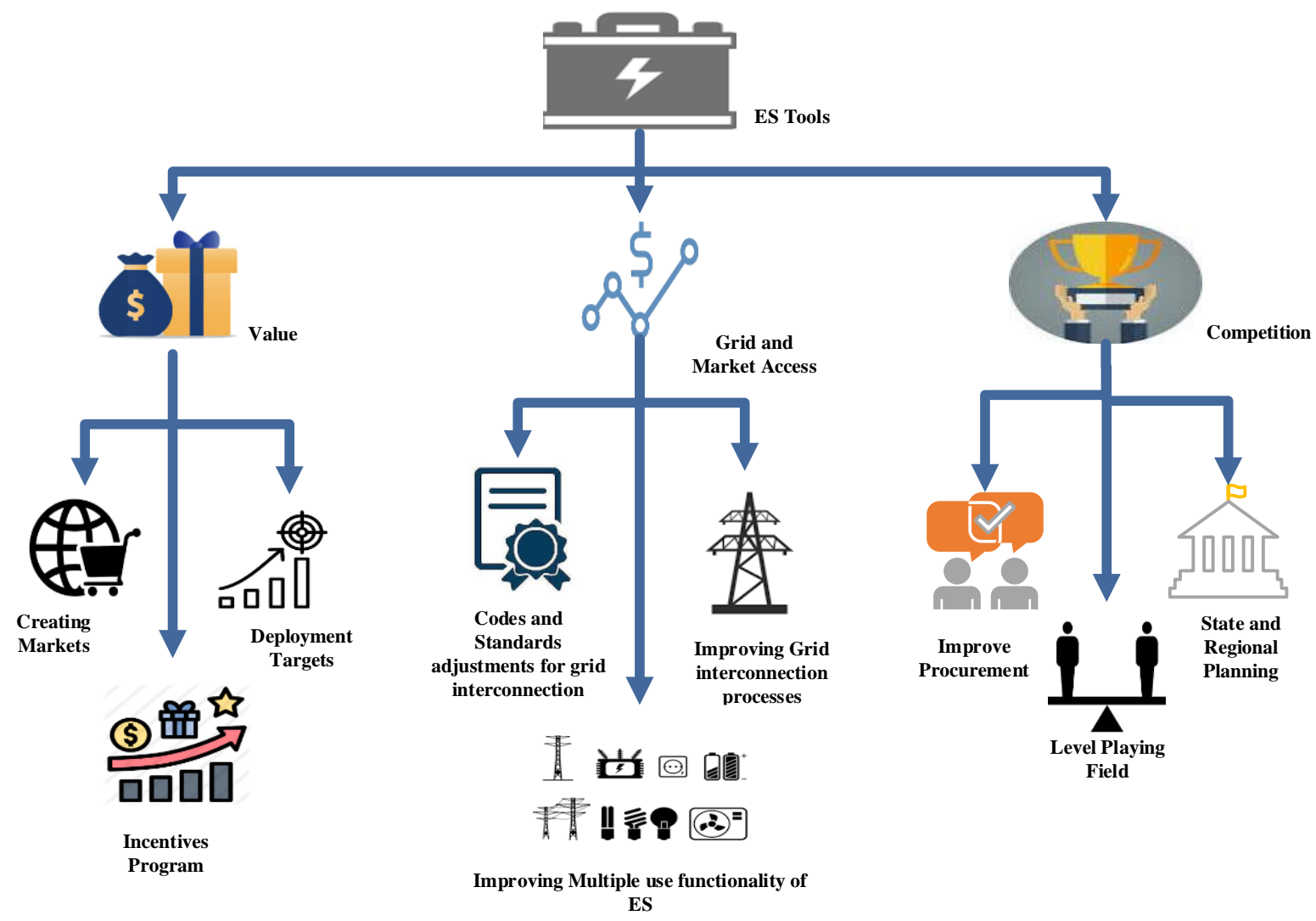

Figure 1: Significant tools considered in ESS policy [10]

\section{Energy Storage System Policies Worldwide}

ESS policies are being introduced worldwide for different reasons though the main reason is because of the enormous benefits in reducing the greenhouse gases emissions. United States (US) and Australia adopted the ESS policies for power systems stability functions. Japan's policies are mainly targeted for emergency power due to the volatile nature of the region to natural disasters, whereas Germany adopted the ESS policies for renewable energy integration into the grid. South Korean policy focuses on peak power reduction for homes and businesses [11]. Even though every country has its area of priority for ESS functions, they are not limited to one specific area and are diversified to take full advantage of ESS whether in power systems, back up or renewable energy integration.

\section{1 $\quad$ United States}

The US regulators have been actively pursuing the efforts associated with the deployment of ESS. They have funded many field exhibitions, energy storage pilots and implementation studies. Both federal and state level governments have pursued policies to promote investment, tax reduction, subsidy support and expansion of public 
supplies with the sole purpose to boost and create new markets for ESS [11]. The state governments have developed installation support policies by requiring companies who meet certain criteria to install ESS and providing subsidies for installations connected with new and renewable sources, while the federal government promotes the investment of enterprises [11].

\subsubsection{Federal}

Earlier this year (2020), the American Energy Innovation Act (AEIA) authorised \$1.4 billion for ESS research development and demonstration (RD\&D) at the US Department of Energy (DOE). This was carried out under section 1301 of the legislation and would last for five years [12].

The Farm Bill in 2019 promoted the ESS projects in rural areas by financing programs administered by the Department of Agriculture which support clean energy projects in farms and small businesses in rural communities [13]. In 2018, the DOE's Advanced Research Projects Agency (ARPA-E) funded a long term energy innovation under Duration Addition to electricity Storage (DAYS) program. The program was to focus on developing technologies that can power the US electrical grid for 100 hours from ESS [14].

The ESS tax incentive bill, S.3159 was proposed in 2016 with the sole purpose of allowing tax credits for ESS with a minimum capacity $5 \mathrm{kWh}$. The incentive also covered ESS systems of different forms such as chemical, electrical, thermal, electrochemical, mechanical and other systems identified by internal revenue services, as long as they store energy by charging and can also discharge when needed $[15,16]$. Homeowners get the same credit as the one that is currently available for solar energy under the Residential Energy Property Tax Credit for ESS. The incentive is only available for battery storage with a minimum capacity of $3 \mathrm{kWh}$ [17].

The Storage 2013 Act was created with the aim of creating equal tax incentives and promoting the deployment of ESS technologies. It provides 30\% investment tax credit to businesses and homeowners for onsite storage to store off peak electricity from the grid or solar PV and $20 \%$ for projects connected to the electric grid and distribution systems[18].

Fast responding ESS sources like flywheels and batteries that bid into frequency regulation markets got an increase on their pay in 2011 under order 755 of the FERC. This was done to promote the ESS used for frequency regulation by giving it reasonable rates [2]. Another step forward for ESS was order 784 of the FERC, which opened ancillary service markets for storage developers. Accounting and financial rules attached to this order guarantees rate recovery for ESS technology. Accuracy and speed requirements for transmission regulation services is ensured under the order [19]. In 2018, order 841 was approved and its main purpose is to remove any barriers for the entry of ESS technologies by Independent System Operators and Regional Transmission Organisations. The FERC believed that this will create healthy competition in the energy grid sector [20].

\subsubsection{State}

ESS has created a lot of interests among several US states, which have taken action to accelerate its deployment by RD\&D and creation of policies to promote it [21]. Five types of state level ESS policies are identified by the Pacific Northwest National Laboratory, as depicted in Figure 2 [22]. These are:

i. Procurement targets: Utilities are given mandates to acquire a certain target of ESS.

ii. Regulatory adaptation: Removing barriers in energy regulations to promote ESS.

iii. Demonstration projects: ESS projects are funded and authorised to see their performance.

iv. Financial incentives: Behind the meter systems are given subsidies and tax incentives. 
v. Consumer protection: Customers with ESS installations are given certain rights by policies set up to protect their interest.

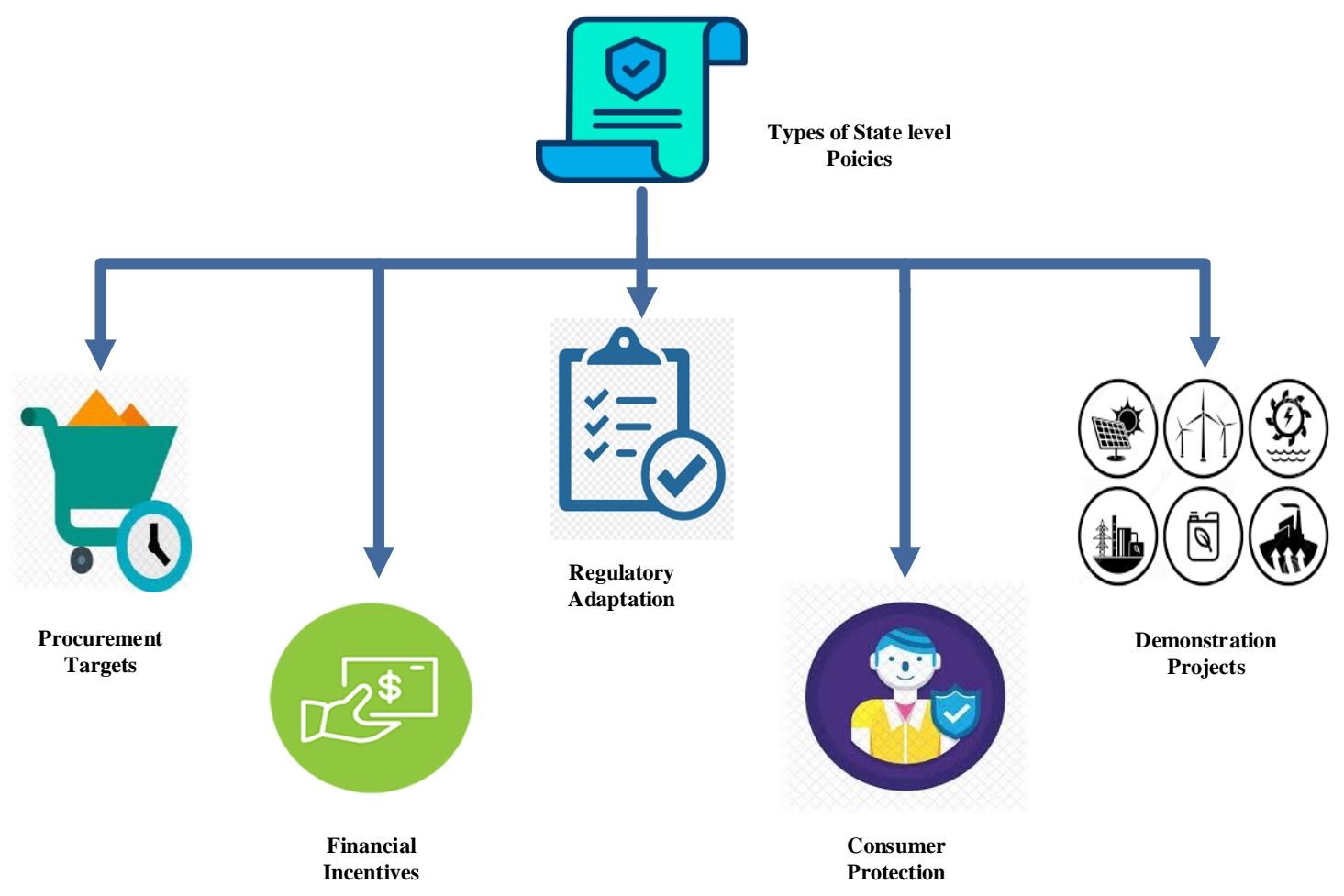

Figure 2: Types of state level ESS policies

Hawaii is diversifying into renewable energy at a fast rate and has a goal of reaching a $100 \%$ renewable energy by 2045. It is because of this that Hawaii Electric has been investing heavily in ESS that will be integrated into the renewable energy power generation [23].

Oregon passed law HB2193 in 2015, which requires that the utilities in the state must have a minimum of 5MWh ESS in service by 2020 [24]. The Arizona State Commissioner in 2018 proposed a target of 3,000 MW in ESS by 2030. This will support the goal of reaching $80 \%$ of electricity energy coming from clean energy by 2050 [25].

California through its state procurement mandate in 2016 and 2017 drove the grid scale ESS market in the US. Bill AB2514 in 2010, required that a target of 1,325MW should be achieved by the state owned utilities by 2020 . The California Public Utility Commission was to supervise it [21]. Due to the promising nature of the bill, another 500MW was added to the mandate [26]. California also passed a bill to make the installation of ESS responsible for 5\% peak power, compulsory by 2020 [11].

Massachusetts in 2016 conducted a review of ESS opportunities and set an aspirational target of 200 MWh to be installed by 2020 [21]. In July 2018, the state passed H.4857, setting a goal of 1000 MWh of ESS by the end of 2025 [14].

In New York, a target of 1500 MW of ESS was set in 2018, to be achieved by 2025 by the Clean Energy Standard (CES). New York has a target of achieving 50\% of electricity used by 2030 to be from renewable energy and to achieve this goal, ESS will play a major role taking care of intermittent issues and grid reliability associated with renewables [27]. New York has allocated a lot of funds for the Clean Energy Fund among which $\$ 60$ million is for 
soft cost ESS reduction and RD\&D. An additional \$200 million for ESS projects has also been invested by the New York Green Bank [28].

In New Jersey, as part of the Action Plan Amendment Number 7, the state launched New Jersey Energy Resilience Bank worth $\$ 210$ million to prevent power disruption and increase network reliability by deploying ESS, distributed generation and smart grid technologies [29]. This will allow New Jersey to invest in fuel cells, solar integrated with storage and other solutions into critical facilities. In order to provide financial support and incentives for storage systems that are incorporated with renewable energy projects, the New Jersey Clean Energy Program was established in 2015 by the Board of Public Utilities [30]. In 2018, A3723 was passed in New Jersey. It set out an ESS target of 2000MW to be achieved by 2030 [14].

Other states in the US have also adopted policies that support the development of ESS. Figure 3 shows a map of the US highlighting states that have adopted ESS policies in green.

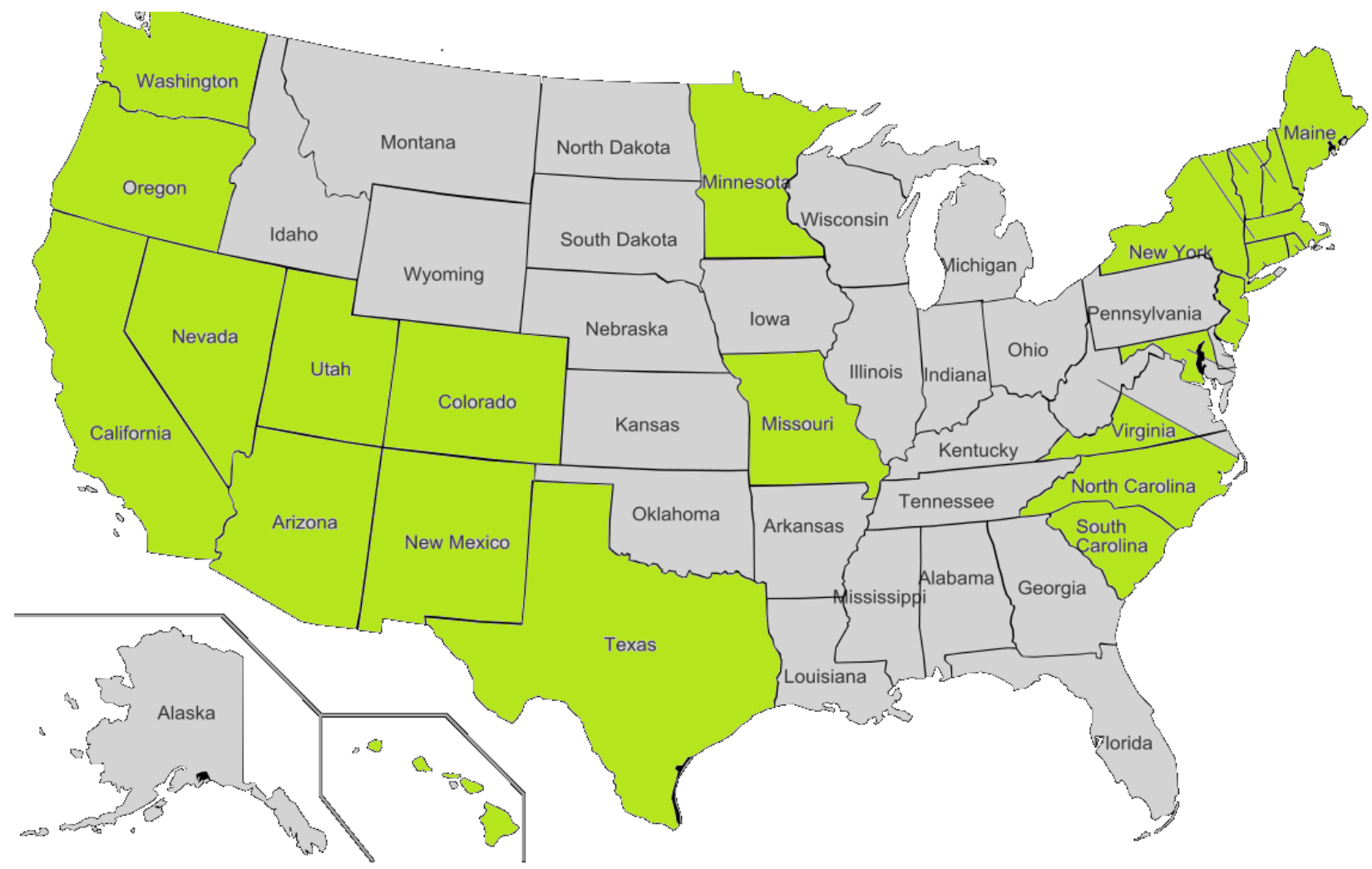

Figure 3: States with ESS policies in US (data obtained from [31])

\subsection{Europe}

Europe under the European Union (EU) has supported the collective renewable energy technologies development and installations to reduce the carbon output from traditional fossil fuel power plants. The intermittent nature of renewable energy sources makes ESS, specifically battery storage the best option to mitigate the challenges. A framework to develop ESS infrastructure to accommodate higher penetration of renewable energy resources was set up. It was named stoRE project. Many countries in the EU are developing their ESS policy so as to adjust or block barriers from existing policies that interfere with the development of ESS policy. Most of the policies are incentives, subsidies and RD\&D based. They are created to study ESS technologies, promote their use and make it attractive for 
the general public. They are also encouraged and supported in the power sector for ancillary services, backup power and so on.

\subsubsection{United Kingdom}

Deployment of storage systems in the UK is not entitled to any direct subsidy. In order to create an ESS and sustainable energy industry that will not be dependent on subsidy, regulatory and policy barriers are being removed by the government. Funding for RD\&D projects for ESS, especially battery storage has also been made available to encourage innovation in the sector [32]. Renewable energy generation and capacity market schemes have levies that are paid by final consumers. Suggestions were made to omit ESS systems from such levies as in most cases they are not the final consumers [33]. This will have a tremendous impact on the adoption of ESS.

The Smart Network Storage project is another policy related to ESS which has a test site that uses renewable sources to charge lithium manganese battery cell technology to supply power to the distribution grid at peak hours [34]. Several 'proof of concept' projects for battery storage have been demonstrated all over the UK to prove that the technology works and will bring more benefits than harm [5]. Some examples of these projects are the Kilroot power station in Northern Ireland and the $10 \mathrm{MW}$ battery storage in Cumbria $[35,36]$.

The enhanced frequency response is a service run by the UK National Grid for the provision of ancillary services to the grid. Eight companies were chosen to provide storage solutions to the grid. The aim of the service is after registering a frequency deviation to provide $100 \%$ active power output at a maximum of one second output [37]. Another initiative was set up in Scotland to encourage the uptake of electric vehicles (EV) is the domestic charge points for EV. The initiative funds about $70 \%$ of the total cost of installation. Charging from home can be done overnight and charging time is expected to be reduced by $30-60 \%$ [38].

\subsubsection{Germany}

KfW Bank in partnership with the German Federal Ministry for Economic Affairs and Energy set out a low interest subsidy and loan scheme for ESS batteries integrated with solar PV and connected to the grid [39]. The Ministry covers $30 \%$ of the energy system cost and it is expected that the PV system will feed in a maximum of $60 \%$ of installed capacity into the grid [2]. The installations of home storage systems both from KfW Bank funding and non-KfW funding in Germany, taken from data and analysis conducted by ISEA RWTH Aachen [40] from 2013 to 2017 is shown in Figure 4. The figure shows a sharp rise in PV battery storage without funding from KfW which indicates that people have accepted the battery storage for PV and the benefits attached to it.

Under the German Renewable Energy Sources Act (EEG), grid tariffs and levies are exempted for in front of the meter ESS facilities. This is as long as the stored energy is fed back into the grid. The EEG was updated in 2017 and the exemptions was expanded under $\$ 61 \mathrm{k}$ for loss of energy and self-supply of storage [32]. Legislation laws such as the $\$ 51(1)$ of the EEG act as a barrier for ESS and promotes renewable energy alone, as it supports the subsidies to continue for 6 hours of negative price periods. These type of laws need to be adjusted as subsidies for negative prices periods do not encourage the development of ESS [32,41]. 


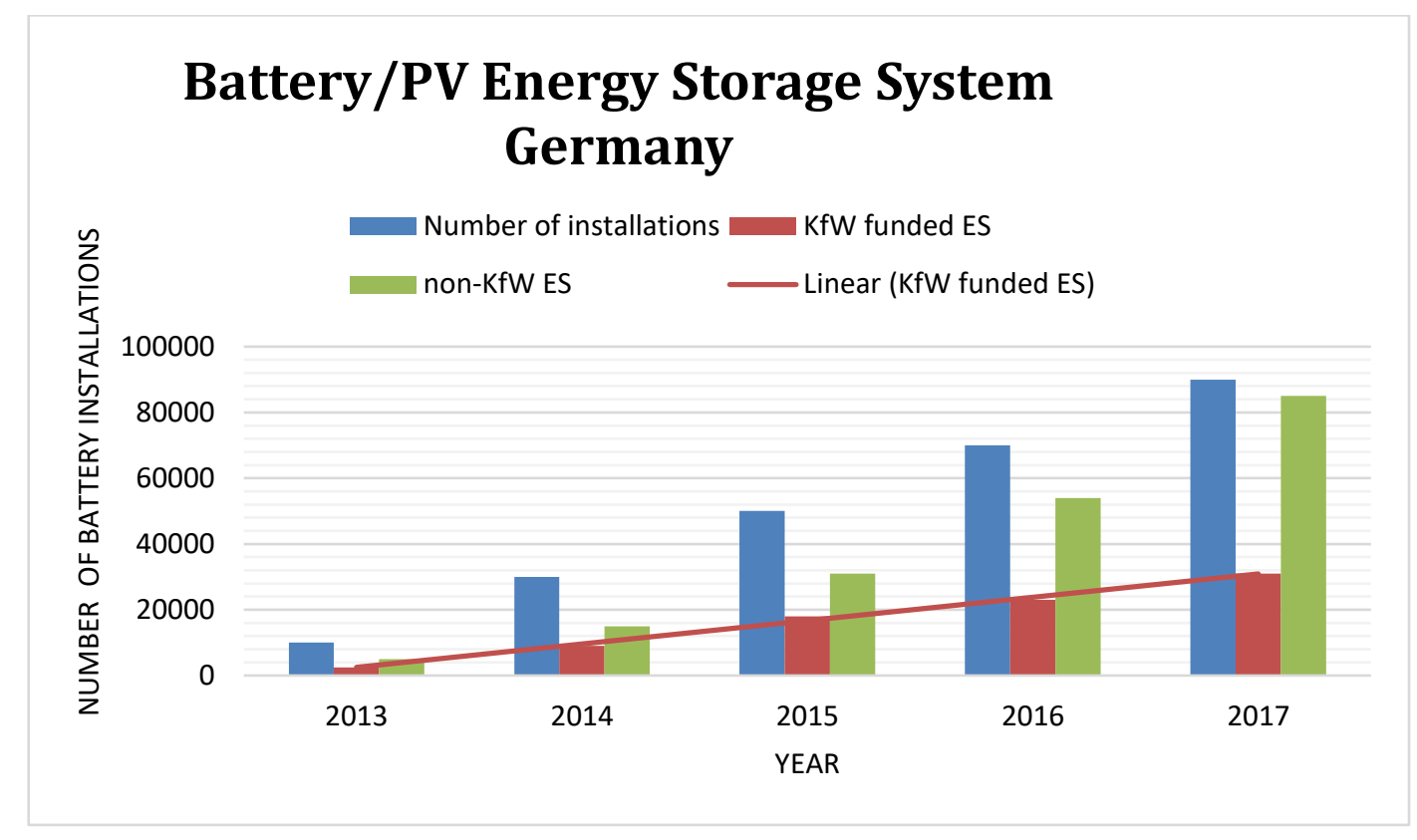

Figure 4: Battery/PV ESS system in Germany [39]

\subsubsection{Other European Union countries}

Other countries in Europe also have initiatives and regulatory frameworks that support ESS. They also have some barriers that slow down the development ESS sector. Table 1 presents some of the initiatives and regulatory frameworks of EU countries.

Table 1: Initiatives and regulatory framework of some EU Countries [32,42-44]

$\begin{array}{lll}\text { Country } & \text { Initiatives and regulatory framework } & \text { Barriers }\end{array}$

Italy National Energy Strategy (NES) was published in 2013, which made a commitment to decarbonisation and reduction of imports of oil, gas and coal.

ESS systems related to sustainable transport and smart grids were to be researched under the NES.

Spain Spain has 17 autonomous regions, with each having parliaments that make their own laws when it comes to energy. The central government provides basic provisions.

Renewable energy systems have a special tariff that is provided through tenders and are given priority dispatch and access.
High grid charges discourage ESS.

ESS initiatives for battery storage are slow as there is no policy to support it.

ESS is considered as generation and are not separately regulated. 
In order to improve the energy efficiency of a solar PV system, a lithium ion battery storage system was set up in Almacena and managed by the grid operator REE.

ESS system installation under the ALISOS project in Tenerife to support renewable energy systems was set up and is being managed by the grid operator REE.

The economic and technical viability of ESS is investigated by three ESS facilities commissioned by Endesa.

Malaga and Barcelona have set up initiatives for smart grids.

Netherlands In the past, abundant fossil fuel supply slowed down the uptake of renewable energy systems.

Public utility companies own regional networks while the national grid is operated by TSO Tennet.

In order to meet international targets and to reduce the emissions of greenhouse gases, the government is promoting power generation from renewable energy sources.

Uptake of ESS is discouraged as adequate legislation to support ESS does not exist.

A temporary regulation was launched in 2015 that encourages electricity experiments by investors in ES and renewable energy systems.

Preferential treatment is giving to investors in renewable energy systems. Tax and levy exemptions are some of the incentives that are given out.

France

A target of $40 \%$ renewable energy target was set for 2030 under the Energy Transition Law. ESS was identified as a means of achieving the objectives of the policy.

A hydrogen plan was set up in 2018 with funding of a $€ 100$ million annually for five years in order to develop the technology and its ESS potential.

ESS is mentioned three times in the French energy code. The first is in L142-9-I where a registry for ESS facilities and electricity generation was placed in
Legislative and financial support for new grid solutions do not exist.

ESS facilities do not have much business interest in the Netherlands.

New Energy solution doesn't have much interest as the national grid has good access to German and French grids.

Battery storage uptake is slow as net-metering is in place.

ESS legal framework for its development does not exist.

Direct injection of electricity into the grid instead of storing it is favoured by feed in tariffs.

Standalone ESS facilities are considered as a consumer when charging and a producer when 
a national register. The second in article L315-1 which states that a plant or a self-consumer can acquire ESS. The third article L121-7 states that public service contribution of electricity (CSPE) will offset any cost of ESS facilities managed by grid operators in non-interconnected areas.

Industries with ESS are given up to $50 \%$ reduction under TURPE 5 with the difference between low consumption hours and peak consumption hours being reinforced. discharging into the grid.

Accessing the grid attracts a double charge because of this translation. This system impacts the adoption of ESS negatively.

\subsection{Asia}

\subsubsection{Japan}

ESS related policies have been around in Japan for a very long time and dates back to 1978 when the Moonlight project was developed by the Ministry of Trade and Industry (METI). It was a ten-year RD\&D program sponsored by the government for research in ESS, gas turbine and heat pump technology [45]. Battery storage and fuel cell was encouraged and supported in the moonlight project in order to reduce Japans dependence on oil imports [46].

In 1980, New Energy and Development Organisation (NEDO) now known as New Energy and Industrial Technology Development Organisation was established [47]. NEDO was set up to find alternatives for ESS like pumped hydro with construction periods that are long, large budgets and environmental factors that are associated with it. Battery technology was thereafter launched alongside renewable and smart grid technology development through the 1980's [46].

In the 1990's, Japan's energy landscape was characterised by deregulation, which gave rise to the commercialisation of increasingly diverse ESS and generation options. In 1993 the New Sunshine Program was formed by combining three of the previous projects with the aim continuing RD\&D for sustainable growth, solving challenges associated with the environment and energy sector [48].

A technology development project was launched by NEDO in 2006 for battery technology. It was to be combined with renewable energy to manage fluctuations [47]. Battery storage project team was set up by METI in 2012. This was done to promote battery technology and storage by creating supportive policies, markets and abiding by international standards of the technology [49].

The Fourth Strategic Energy Plan was launched in 2014 with the primary objective of promotion and establishment of a multi layered energy supply system that is resilient and will ensure stable energy supply [50]. "The $3 \mathrm{E}+\mathrm{S}$ ” principle was developed with the policy objectives given as follows:

- $\quad$ Energy Security

- $\quad$ Economic Efficiency

- Environmental Sustainability

- $\quad$ Safety

After the Fukushima nuclear power plant accident, the energy market has changed significantly in Japan with the rise of smart city plans and higher uptake on renewable energy. All of these systems are only possible with ESS to regulate energy demand management systems [46]. The Energy plan launched in 2014 encouraged renewable energy 
systems and also promoted energy efficient management system (EMS). The reduction of nuclear energy power plants and systems was encouraged [51]. Japan has supported policies to provide a third of total expenses with government subsidies and other support programs for ESS to prepare for unstable power issues after natural disasters [11].

The relevant regulatory and legal architecture of Japan's ESS market is shown in Table 2. The Fire Prevention Ordinance and the Electricity Business Act made a distinction between small and large scale ESS usage. Technical standards and regulatory guidelines outline grid connection norms [52].

Table 2: Regulatory Structure of Japan’s Energy Storage [52]

\begin{tabular}{|c|c|c|c|}
\hline Type & \multicolumn{2}{|l|}{ Regulatory Structure } & Governing Organisations \\
\hline \multirow[t]{3}{*}{$\begin{array}{l}\text { Guideline } \\
\text { (Technical } \\
\text { Requirement) }\end{array}$} & \multicolumn{2}{|c|}{$\begin{array}{l}\text { Technical requirements guideline of grid } \\
\text { interconnection to secure electricity quality (2004, } \\
\text { revised in 2013) }\end{array}$} & $\begin{array}{l}\text { Ministry of Economy, } \\
\text { Trade and Industry } \\
\text { (METI) }\end{array}$ \\
\hline & \multicolumn{2}{|c|}{$\begin{array}{l}\text { Grid Interconnection Code (JEAC 9701-2006) } \\
\text { (superseded by JEAC 9701-2012.) }\end{array}$} & $\begin{array}{l}\text { Japan Electric Association } \\
\text { (JEA) }\end{array}$ \\
\hline & Electricity Business Act & $\begin{array}{l}\text { Required approval for } \\
\text { large electricity storage } \\
\text { system more than } \\
80,000 \mathrm{kWh}\end{array}$ & $\begin{array}{l}\text { Ministry of Economy, } \\
\text { Trade and Industry } \\
\text { (METI) }\end{array}$ \\
\hline \multirow{3}{*}{$\begin{array}{l}\text { Relevant } \\
\text { Legislation }\end{array}$} & Fire Service Act & $\begin{array}{l}\text { Dangerous material for } \\
\text { more than } 1,000 \ell \\
\text { organic } \\
\text { solution }\end{array}$ & \multirow{2}{*}{$\begin{array}{l}\text { Fire and Disaster } \\
\text { Management Agency, } \\
\text { Ministry of internal affairs } \\
\text { and Communications }\end{array}$} \\
\hline & Fire Prevention Ordinance & $\begin{array}{l}\text { Required approval for } \\
\text { large battery } \\
(4,800 \mathrm{Ah} / \mathrm{cell})\end{array}$ & \\
\hline & Building Standards Act & $\begin{array}{l}\text { Construction application } \\
\text { for building regarding to } \\
\text { fire prevention property }\end{array}$ & $\begin{array}{l}\text { Ministry of Land, } \\
\text { Infrastructure, } \\
\text { Transport and Tourism }\end{array}$ \\
\hline
\end{tabular}

Larger capacity ESS poses more energy supply risk for integration into the grid and more of a safety risk on its own than a small scale ESS system. It is because of this that the regulations and laws are more involved in the larger scale ESS in Japan. The small scale ESS users are mostly for residential use and small businesses and normally use small batteries that do not necessarily connect to the grid. Because of the nature of small scale batteries, the Fire Prevention Ordinance does not regulate it and rather concentrates on large scale ESS facilities and sites [46].

METI in 2012 set out an ambitious target of gaining 50\% market share of the world's battery storage market by 2020 alongside its battery storage strategy. It also aims to capture $25 \%$ of industrial/residential battery storage market and $35 \%$ large scale battery world market share $[50,52]$. 


\subsubsection{China}

From 2005 onwards, China's central government promoted many policies for the development of ESS industries. The policies targeted different aspects that can progress and ensure the rapid development of ESS such as market development, grid connected operation management, development pattern environmental protection and financial support [53].

The central government concentrated on a lot of RD\&D ESS projects especially on batteries. One of such projects is the Zhangbei $36 \mathrm{MWh}$ lithium ion battery ESS which was installed to evaluate the value and kind of services it can add to the grid [2]. Due to the rapid deployment of renewable energy power generating systems, the integration of ESS and renewable energy such as solar PV and wind was given priority. Development of ESS in distributed micro grids and distribution and transmission was also given major attention. This was all done in order to pave way for the smooth transition and development of ESS in China.

The ESS technology and industrial development promoting guideline in China plans to promote ESS by carrying out demonstration projects and then commercialisation. It encouraged the demonstration projects to be continuously carried out as long as there are new technological innovations. The information and control of ESS should be improved by combining it with energy internet [54]. Table 3 lists some of the policies related to ESS in China.

Table 3: Policies related to ESS in China

\begin{tabular}{|c|c|c|c|}
\hline Laws and Regulations & Objectives & Year & Reference \\
\hline $\begin{array}{l}\text { Renewable Energy Law of } \\
\text { China and its amendment }\end{array}$ & $\begin{array}{l}\text { ESS technologies should be } \\
\text { developed and applied from a } \\
\text { national legal documents } \\
\text { perspective. }\end{array}$ & $\begin{array}{l}\text { Published in } \\
2005 \text {;amended } \\
\text { in } 2009\end{array}$ & [55] \\
\hline $\begin{array}{l}\text { Catalogue for the guidance of } \\
\text { the renewable energy industry } \\
\text { development }\end{array}$ & $\begin{array}{l}\text { Increase scale of ESS batteries and } \\
\text { rapid commercialization. }\end{array}$ & 2005 & [56] \\
\hline $\begin{array}{l}\text { The national medium and long } \\
\text { term development plan for } \\
\text { science and technology 2006- } \\
2020\end{array}$ & $\begin{array}{l}\text { Development of ESS technology } \\
\text { and materials from a technological } \\
\text { point is supported. }\end{array}$ & 2006 & [57] \\
\hline $\begin{array}{l}\text { 12th Five Year Plan for } \\
\text { intelligent network }\end{array}$ & $\begin{array}{l}\text { Basic work on electrochemical } \\
\text { ESS is carried out, the role of ESS } \\
\text { in smart grid, distribution and } \\
\text { power generation is defined. }\end{array}$ & 2011 & [58] \\
\hline $\begin{array}{l}\text { Twelfth Five Year Plan for } \\
\text { National Economic and Social }\end{array}$ & $\begin{array}{l}\text { ESS is used in smart power grids } \\
\text { as technical support. }\end{array}$ & 2011 & [59] \\
\hline
\end{tabular}

Development of the People's

Republic of China 
Notice on Formulating the

Thirteenth Five-Year Plan for the Development of Solar

Energy

Guiding Opinions on

Implementing the

Demonstration Projects on New

Energy Micro grids

Opinions on Further Deepening the Reform of the Electric

Power System

Thirteenth Five Year Plan for National Economic and Social Development of the People's Republic of China

Notice on the Publication of the Thirteenth Five Year Plan for Renewable Energy

Development

Notice on Promoting the Pilot Work of Participation of

Electric ESS in the

Compensation (Market)

Mechanism for Electricity

Ancillary Services in Northeast

China, North China, and

Northwest China
An energy system that combines

2014

[60] ESS with solar PV should be build.

ESS with sufficient reaction time and capacity should be constructed into energy micro grids.

Micro power grids that incorporate information and advanced ESS technologies should be actively developed.

RD\&D for large scale ESS application should be promoted.

1) The application of ESS in renewable energy field should be promoted.

2) Development pattern of ESS that is suited to that of renewable energy should be explored.

3) Specification for grid access, technical standards, testing and certification process should be perfected.

4) ESS technology business pattern should be explored.

Ancillary services of ESS devices are promoted. 
Notice on Releasing the Measures of Technical Policy for the Lead-acid Production and Renewable Pollution Control, and of Technical Policy for the Pollution Control of Waste Batteries

Notice on Releasing the Thirteenth Five-Year Plan for Energy Development
Cleaner production and ecological

2016 design of lead acid batteries.

2017 [66]
1) Carry out demonstration of ESS projects.

2) Distributed energy grids underpinned by ESS technologies should be developed.

3) Electric power systems, new energy systems and ESS optimised and coordinated operation should be promoted.

\subsubsection{South Korea}

In May 2011, South Korea established Energy Storage Technology Development and Industrialization Strategies (K-ESS 2020), and has propelled technology development and demonstration projects in order to study the behaviour and promote the use of ESS [11].

The central government has shown tremendous support for innovative energy systems, which includes the usage of ESS within Energy Management Systems and smart grids, the government in 2014 planned to install $500 \mathrm{kWh}$ of ESS. The Korea Electric Power Corporation also planned to install $1000 \mathrm{kWh}$ of storage [2]. Through the Ministry of Trade, Industry, and Energy (MOTIE), customised electricity rates have been created to uplift the ESS and EV industries, attracting investment in storage and the use of eco-friendly EVs by consumers [67]. Installation of different ESS by small and medium enterprises was also supported with incentives.

In order to encourage expansion of the installation of ESS in Korea, the Electricity Charge Discount Program (ECDP) was implemented in 2015. The program works by giving a discount rate for electricity when charging the ESS at light load and when the ESS reduces peak load by discharging during the peak period. The electricity bill will then be discounted based on the peak load reduction [6]. For the purpose of enhancing the effectiveness of the ECDP incentive, the government in 2017 implemented a policy that will temporarily increase the discount rate depending on the ratio of the battery storage capacity to contract power of the electricity customer [6]. The incentive will encourage the rapid adoption of battery storage because of the benefit of discounted electricity bill attached to it.

\subsection{Australia}

In 2012, the Australian Renewable Energy Agency (ARENA) was established under the ARENA Act 2011 with the sole aim of driving down the cost and increasing the use of renewable energy. ARENA at present is the key 
mechanism supporting ESS development in Australia and has identified that ESS can play an important role in achieving the aims and objectives of the agency which is why it has invested heavily on battery storage [68].

The South Australian (SA) government made a low carbon investment plan policy strategy in 2015. It invested heavily in its low carbon energy and has already reached $52.1 \%$ of renewable energy penetration [69]. ESS has gained a lot of support and investment in this project and will be used mainly to prevent power quality and curtailment issues that might arise from intermittency of renewable energy systems [70]. In 2015 under the sustainable city incentive scheme, direct financial incentives were offered for battery storage attached to solar PV installations by the Adelaide City Council, making it the first government in Australia to offer such incentives. The scheme targeted business owners, residential buildings, community groups and schools with such installations. Shortly after the scheme commenced and the promising nature started to show, the SA government matched the funding of Adelaide city council to install close to $600 \mathrm{kWh}$ of battery energy storage [71]. In October 2018, the home battery scheme was launched by the SA government to provide subsidy for residential customers to install battery with their roof top solar PV systems [72]. SA government also has installed the world's largest Li-ion battery (100MW/129MWh), the Hornsdale power reserve to provide the essential grid support services [73].

The Australian Capital Territory (ACT) has an ambitious renewable energy target of $100 \%$ by 2025 which is supported by the sustainable energy policy framework launched in 2011. Battery ESS is viewed by the government as playing a vital role in achieving some of the objectives of the policy [74]. The Next Generation Renewables is one of the programs the government has implemented in order to facilitate the installation of $36 \mathrm{MW}$ of battery storage across 5000 homes and businesses between 2016-2020 [75].

The Renewable Energy Industry Development Strategy (REIDS) is another initiative that was designed to support growth in the clean economy. The main focus of REIDS is to develop the renewable energy industry in the ACT such as solar and wind together with ESS. It is supported through the development of renewable energy test facilities and a business research precinct with the collaboration of government and industry [76].

In order to support, promote and encourage the use of ESS in Australia, thirteen possible market reforms have been suggested by the Clean Energy Council. The reforms have been summarised under the following categories:

- Level the playing field

- Removal of regulatory barriers to behind the meter ESS

- Reward and recognise the value of storage behind the meter

- Protect Consumers and establish standards

Table 4 gives the breakdown of the reforms suggested by Clean Energy Council.

Table 4: Reforms suggested by the Clean Energy Council for Australia [77]

ACTION REFORM

Level the playing field

1. Energy market settlement regime should be reformed to provide a better market signal for energy by adopting a five minute market settlement approach.

2. Frequency control regime should be reformed to allow fast acting ESS to help with frequency control and system security.

3. Options to address electricity market rules that prevents investment in network services and concentrates on wires and poles should be reviewed by The Australian Energy Market Commission (AEMC). 
Behind the meter storage regulatory barriers should be removed

Recognise and reward the value of storage behind the meter

Consumer Protection and Standards should be established
4. Better data should be published on impending network constraints by distribution businesses that can be fixed by ESS investments. The AEMC and Australian Energy Regulator (AER) should consider changing the annual planning reports by distribution systems to a geographic information system driven portal for better data and market access.

5. Optimal increment pricing' which allows gradual increments of investment while reducing administrative burden on distribution businesses should be encouraged by the AEMC by lowering the regulatory investment test for distribution (RIT-D) test from the current $\$ 5$ million threshold.

6. The addition of a battery to an existing solar PV system should be made easier to achieve by distribution businesses by clearly stating the technical difference between the two and pointing out the impact they have on the grid.

7. The value of ESS should be appreciated by supporting benefit reflective feed in tariffs by territory and state governments.

8. Premium feed in tariffs customers should be allowed to trade the value of the tariff for a subsidy on a battery.

9. Demand charges should be updated on the Australian Energy Regulator (AER) online comparison tool and transition to demand based tariff should be supported.

10. Safety regulators of state governments should make sure that installation of battery storage should be carried out by professionals accredited by Clean Energy Council Scheme.

11. An Australian Standard for lithium ion batteries product safety should be created. Until then international product standard for battery safety such as IEC 62619:2017 should be considered by regulators.

12. Tender conditions should be specified for behind the meter battery storage systems that benefit from rebates from the government. The conditions should specify either compliance with standards like the Solar retailer code of conduct or the use of retailers that are signatories to the Solar retailer code of conduct.

13. The government should work out a way to recycle, reuse or dispose of batteries when they are no longer functional.

\section{$4 \quad$ Impact of Energy Storage System Policy}

ESS policies are the reason storage technologies are developing and being utilised at a very high rate. Storage technologies are now moving in parallel with renewable energy technology in terms of development as they support each other. ESS is a bridge in the process of achieving clean and sustainable energy from renewable power generating systems and providing ancillary services for power systems. The variable nature of renewable energy technology such as wind and solar PV make it unreliable and does not produce constant and stable power output. The integration with 
ESS mitigates that problem by storing the energy and providing it when needed. ESS is also used in power sector for grid stability.

ESS through increasing the utilisation of installed resources and supporting greater penetration rates of lower cost carbon resources can reduce the power generation costs [78]. ESS can serve as backup for residential houses and business in areas with unstable power supply or during unplanned outages. Depending on the capacity of the ESS, it can provide power for a couple of hours to a few days. This will prevent unnecessary expenditure that might be incurred from damages of goods and services that need electricity power. It also saves money that would have been used for providing alternative power through other sources like diesel generator during the outage. ESS through energy arbitrage can bring down operational costs in the grid. Cost of grid maintenance from spinning reserve services and frequency regulation is brought down tremendously by ESS [79]. Consumers of electricity can reduce their utility bill by storing energy during off peak periods when it is cheap and using it during peak periods when it is expensive [80].

From 2013-2018, there has been a steady increase in the installation of ESS worldwide. There was a drop in 2019 mainly due to slow progress and uncertainty in establishing regulations and rules for its use and deployment. Behind the meter installations were consistent in growth while grid scale storage dropped by $20 \%$ [81].

Figure 5 presents the annual growth of ESS worldwide from 2013-2019

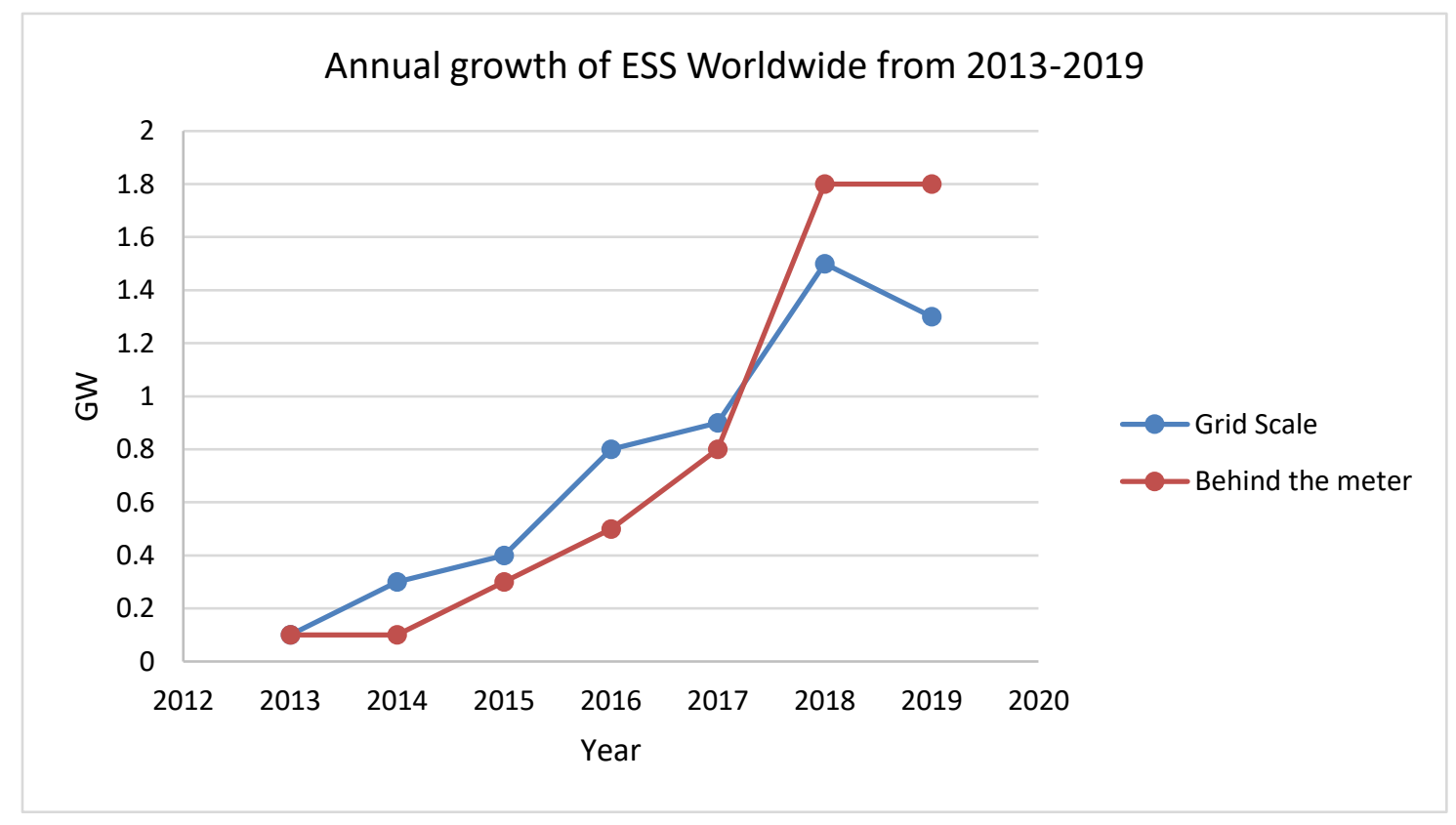

Figure 5: Annual growth of ESS worldwide from 2013-2019 [81]

Most of the jurisdictions that have adopted ESS policies have the common goal of going green in the long run. Due to depleting fossil fuels, they are seeking for an alternative energy sources that is cleaner and equally as effective. Existing grid infrastructure and electricity demand profiles influence the environmental impacts [82]. ESS policy supports the transition toward a low-carbon economy (decarbonisation) by helping to integrate higher levels of variable renewable resources, by allowing for a more resilient, reliable, and flexible electricity grid and promoting greater production of energy where it is consumed [78].

ESS policy supports integration of diverse renewable energy resources into the grid and independently for private use. It offers a new carbon free source of operational flexibility, that improves the utilization of generation assets [83]. 
The International Energy Agency (IEA) estimates that in the first quarter of 2020, 30\% of the global electricity supply was provided by renewable energy [84].

ESS policy has made a positive impact on transport storage by providing alternatives to fossil fuels such as battery, super-capacitor and fuel cells. ESS policy has supported the RD\&D of transport storage and can be attributed to the rampant development of EV sector. With supportive policies, battery powered vehicles will be competing with conventional combustion powered vehicles in terms of cost, durability and reliability [85].

It can be summarised that the major impacts of ESS policies are as follows: i) ESS helps save operational costs for the grid and consumers, ii) reduce negative environmental impacts, iii) act as support for renewable energy sources, iv) improve resilience and reliability of the grid, and v) promote transport storage [80]. All of these are achieved by the policies eliminating barriers, providing a fair chance for ESS, encouraging RD\&D and providing incentives for ESS. Figure 5 shows the impacts of ESS.

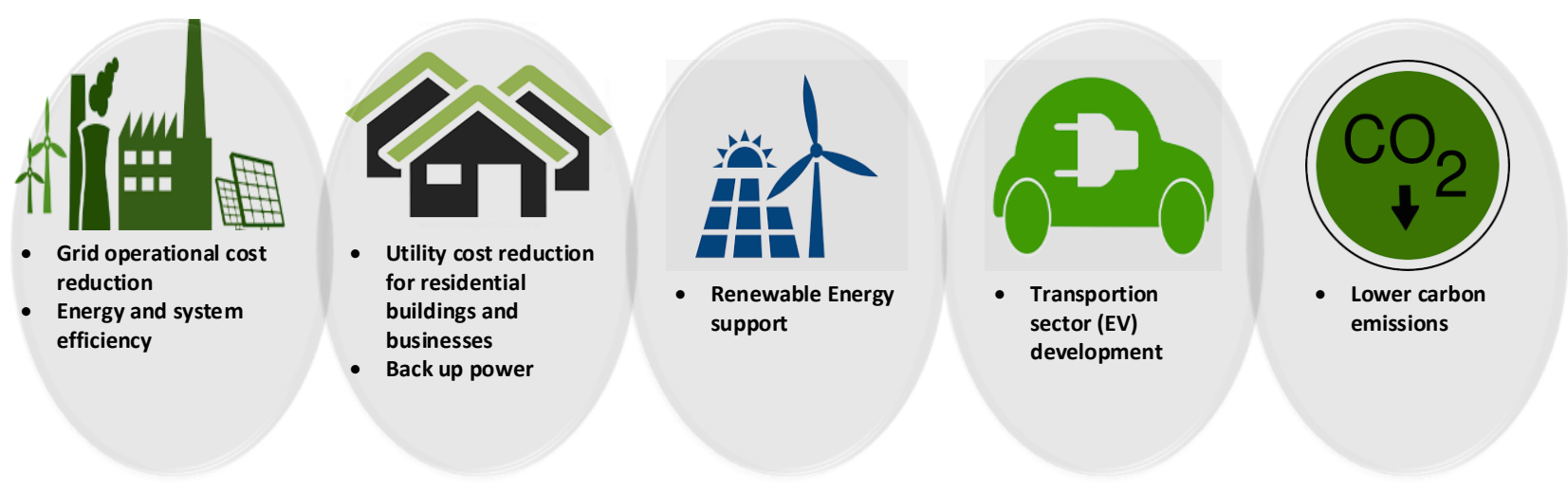

Figure 6: Impact of ESS Policy

\section{$5 \quad$ Barriers and Opportunities for Emerging Economies}

Climate change mitigation and energy efficiency are some of the main reasons considered for ESS policy by countries that have adopted them. Emerging economies need these policies for the same reasons, but also as a way to increase the power generation capacity and create opportunities in the energy sector [86]. Identifying and removing barriers will unleash the opportunities of ESS policy for emerging economies. Some of the barriers commonly observed in emerging economies are classified into financial, institutional and technological barriers [87]. Figure 6 presents the barriers of ESS policy in emerging economies.

The cost of ESS will strongly determine the success or failure of ESS policy in emerging economies. The major role of the government is to create policy that will give private industry players a conducive atmosphere to thrive and develop ESS technology. Most of the governments of countries that have adopted ESS policy only invest in RD\&D projects and are not directly involved in the running of the business or sector, but merely manage it with policies and encourage it with RD\&D support. Emerging economies have the opportunity to invest heavily in the renewable energy and ESS industry. Companies can be set up to feed local demand, making solar panels, wind turbines and various forms of ESS. This will create employment and technical knowledge of the sector. It will also bring down the cost of ESS due to local production.

Key challenges for the adoption of ESS that need to be addressed are [88]

- Market and Regulatory guidelines: rules that are distorting the market and chasing away investment have to be removed or redefined. ESS provides different services for different players and often leads to uncertainty as to the applicable regulations for a given project. 
- Cost Effectiveness: $30 \%-40 \%$ of the total system cost is the actual ESS technology while the rest is for engineering, auxiliary technologies, integration and other services. Expenses especially on other costs apart from the actual ESS technology must be reduced.

- Safety and Performance perception: Performance of ESS within a larger network has to gain the confidence of grid operators. The acceptance can be facilitated by modelling and simulation tools.

- Cooperation from multiple stakeholders: Different stakeholders ranging from facility and technology owners, investors, electric utilities, insurers and project developers have different views and concerns. Reaching an understanding between the stakeholders is a major challenge.

ESS policy has a lot of opportunities that can be gained from it. These opportunities are grid stability, environmental protection, renewable energy integration and EV market development. The opportunities are presented in the next 4 paragraphs.

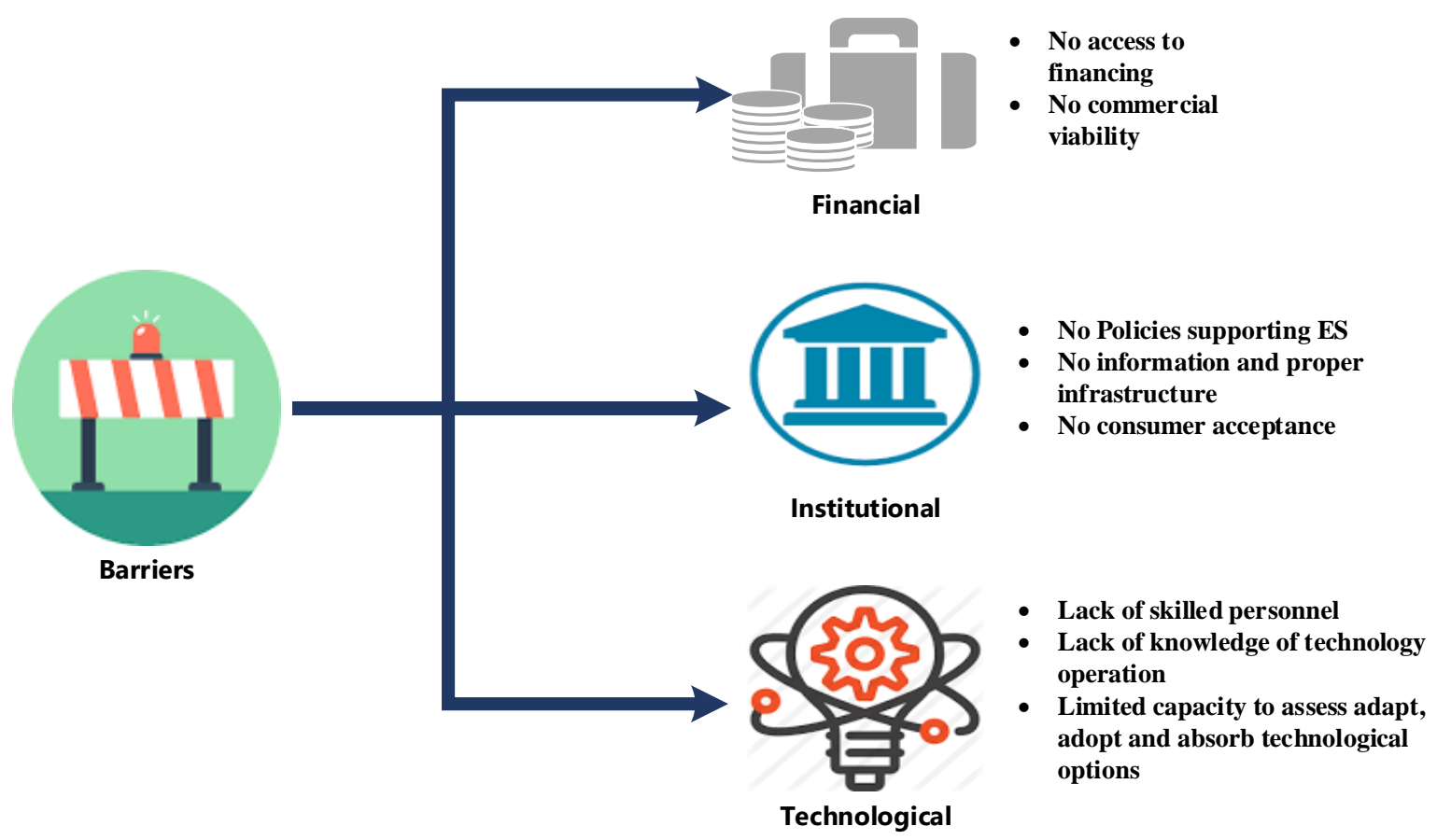

Figure 7: Barriers of ESS policy in emerging economies [87]

\subsection{Grid Stability}

Unstable power supply is a common phenomenon in emerging economies. It is either the generation is lower than the demand or the power is unstable due to bad maintenance and aged equipment. ESS like battery, flywheel and super-capacitor can be used in grid stability and as temporary emergency power in designated areas in case of a power outage [89]. Battery storage can be used for frequency regulation, which will reduce blackouts and operational cost tremendously. System stability will also be achieved. In South Africa, the national utility company, Eskom is developing its battery storage capacity for grid stability. The Central African Republic and Gambia are also 
considering battery storage for grid stability [90]. ESS policies will create an avenue for the use of ESS in the grid for power stability in emerging economies.

\subsection{Environmental Protection}

The most important reason for adopting ESS policy is the environment. This can be looked at from many angles such as, i) reducing greenhouse carbon emissions to meet global targets, ii) installing ESS as emergency back up to areas that are prone to natural disasters such as earthquakes, tsunami, hurricanes and iii) Protection of natural ecosystems from the disruptive creation of power plants and dams. Whatever the case, environmental protection can be achieved with good ESS policy. Storage systems reduce wastage of electricity by storing excess energy to be used at a later time when needed. They also serve as alternatives that can be used in micro grids as part of a power generating system instead of construction of new power plants.

\subsection{Renewable Energy Integration}

Renewable energy power generating sources have seen a rapid influx in the markets of emerging economies and developed countries especially due to the rapid drop in global price and increased competition in the sector. The most common renewable energy technology is wind turbine followed by solar PV [91]. These can be connected to the grid or used privately as a power source. The only downfall of these technologies is they are intermittent and take up a lot of space. Battery storage integrated with renewable energy sources makes a perfect and balanced system [92]. Majority of emerging economies are located in regions with abundant sunshine and wind, which makes them perfect candidates for the renewable energy and battery storage systems.

Creating ESS policy that will support renewable energy integration and behind or in front of the meter battery storage will be a bonus for such countries as they will be reducing the carbon emissions. It will also save a lot of money for connecting and maintenance of isolated areas to the grid. These areas can be made off grid with their own independent power system.

\subsection{Electric Vehicle}

The EV market in emerging economies will be promoted with the right ESS policy. Renewable energy power sources can charge EV directly or indirectly by storing the charge in a battery to be used for charging the EV when required. EV development in emerging economies is slow mainly because of lack of facilities and cost. This can be cushioned by the governments providing soft loans and incentives [93]. Bulk of the global emissions of greenhouse gases are from the transport sector with the US, China and India contributing nearly 50\% of it [94]. EVs have less emissions than conventional vehicles and could be the perfect remedy for carbon emissions reduction [95].

Countries that have a localized car production industry have an advantage when it comes to EV adoption and manufacturing as they can acquire the technology and start local production. With local production and RD\&D comes reduced cost and knowledge in the field [9]. China has done very well in the EV sector as it is currently the largest manufacturer of EV, India is slowly catching up and even has a target of 100\% e-mobility by 2030 [94].

Figure 7 illustrates some of the opportunities of ESS policy in emerging economies. 


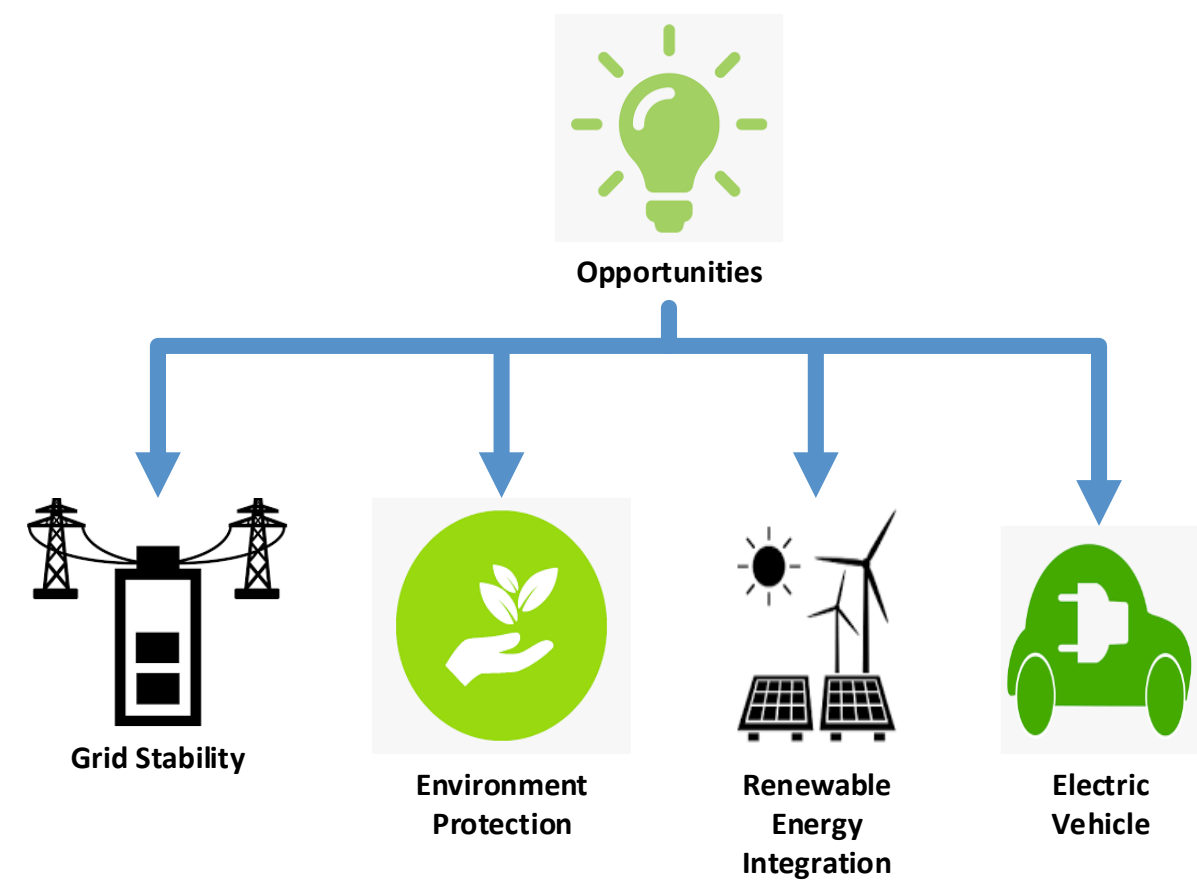

Figure 8: Opportunities for emerging economies [87]

\section{Discussion on Way Forward}

Countries willing to adopt ESS policy must first of all identify the benefits attached to it, they must identify the added value it will bring and they must also carry out a financial analysis on how much it will cost the country to implement the policy. Pilot studies should be carried out to explore the viability of the policy. Area of implementation of intended policies must be identified. They must explore potential challenges that might come up and prepare for them. They must also be ready to provide financial support for RD\&D. They must promote and encourage ESS education and technology, so that the technical know-how is known by local engineers and scientist both in the industry and government.

The purpose of the policies is to adjust barriers in order to promote and develop ESS and to carry out RD\&D projects. This is done by providing incentives, soft loans and in some cases, subsidy for ESS installation by the government and industry players. ESS policies become important when some countries start thinking of alternatives to reduce the dependency on fossil fuels and its negative side effects for power generation. High cost of ESS is the most significant barrier to its deployment. In certain situations, ESS maybe the preferred economic alternative as several recent deployments indicate that capital costs are decreasing. Other barriers may still limit further deployment. These barriers can be broken down into technology barriers, cross-cutting barriers, developer business model barriers, economic barriers and regulatory barriers [7]. One of the major pushers of ESS policies is the rapid penetration of renewable energy power generation, which is intermittent in nature and needs the support of ESS to provide ancillary services and store energy for use at a later stage.

ESS policies are predominantly made by countries with developed economies. These countries have the expertise and take advantage of the resources they have by investing heavily in ESS sector and renewable energy sources. The economy of a country plays a major role in the adoption of ESS. It is not cheap and having a good economy means having extra money to invest on every aspect of ESS. Rapid development of RE technology in these countries gives them an edge. ESS friendly policies pave the way for the growth of the technology and application of ESS in different sectors. Another reason for these jurisdictions progress in ESS adoption is that majority of the populace are educated about ESS and know the values attached to it. They welcome it as a solution to many problems like greenhouse gas emissions, backup power and saving costs on electricity bill. 
International Energy Agency (IEA) estimates that in 2020, emerging economies will need to double their effort to meet rising electricity power demand. Power generation has to be improved significantly and a large chunk of the generation should preferably be from renewable energy sources [96]. Electricity supply in most emerging economies is still low and needs urgent attention especially with the growing population. Rural areas that do not have access to electricity are many in number and centralised grids are not ideal for such areas as it will be expensive to transmit power there and to maintain it. The solution is off grid or semi off grid systems. These systems can have battery storage integrated with renewable energy power sources. The price of solar PV, wind turbines and batteries have significantly dropped over the last couple of years. This has made it easier to procure and install them [97].

Emerging concerns around end of life management of advanced batteries and concerns over the impact of upstream lithium extraction are a major topic of discussion. This can be seen as another challenge that needs urgent attention. Possible solution to this problem will be to reuse and recycle the battery. The battery from the onset and initial design can be made in a way that is friendly for reusing and recycling so that the cost associated with refurbishing it will be drastically reduced. The lifetime of li-ion battery can be extended by operating it under strict safety guidelines and standards. They can also be reused in other applications other than the one that they were initially intended for. For example, batteries integrated with renewables for irrigation systems or backup power systems may not need the same performance characteristics as commercial grid systems [98]. Second life use of batteries can reduce the demand for new batteries, saving on cost and reducing pollution from lithium extraction.

Recycling of aged batteries reduces solid waste streams and allows for the recovery of useful materials such as cobalt, graphite and nickel. This will have a positive impact on the mining of the raw material as it will bring the demand down and energy and environmental burdens will be drastically reduced [99].

ESS policies discussed in the previous sections for different countries could be studied and tuned to be applicable in emerging economies. This should be done to harness the development of the ESS market and encourage the use of renewable energy sources. ESS policies will provide a conducive atmosphere for storage to prosper in emerging economies. They will bring with them the added advantage of saving money on electrical installation in the long run and lowering the carbon emissions. Incentives are always a good idea to promote ESS. These could be tax waivers, free rent for ESS facilities or land and so on. Subsidy on ESS in the long run might not be a good idea as it will cost the government a lot of money.

\section{Conclusion}

A comprehensive review of existing ESS policy worldwide is presented and samples from different countries are discussed. ESS policies are rather new in most countries The need to reduce greenhouse gas emissions and the influx of renewable energy systems and technology has boosted the use of ESS. Battery storage is the most common and fastest growing ESS in the world at the moment. Most of the ESS policies revolve around battery storage as they can easily be integrated into the grid, renewable energy, used in electric vehicles and used as backup power. Most of the policies are centred around encouraging the use of ESS by providing incentives, soft loans to the public and businesses and creating a level playing field for ESS to compete with other energy systems. RD\&D projects are also being carried out. ESS policies are predominantly present in developed economies as they have the expertise and resources for ESS. Growing renewable energy market in emerging economies and greater awareness of global warming makes ESS attractive. ESS policy will make positive impact and open a lot of opportunities for emerging economies. Some of the benefits that were identified to be gained from ESS policies are grid stability, renewable energy integration and environmental protection. It is hoped that countries without ESS policy especially in the emerging economies will learn from countries that have adopted them, to assist entities that want to drive change in their community. 


\section{Acknowledgement}

This research was supported by the Long Term Research Grant (LRGS), Ministry of Education Malaysia for the program titled "Decarbonisation of Grid with an Optimal Controller and Energy Management for Energy Storage System in Microgrid Applications.

\section{References}

[1] K.R. Vasudevan, V.K. Ramachandaramurthy, G. Venugopal, B. Ekanayake, S.K. Tiong, Variable speed pumped hydro storage: A review of converters, controls and energy management strategies, Renew. Sustain. Energy Rev. 135 (2020) 110156. https://doi.org/10.1016/j.rser.2020.110156.

[2] Renewable Energy Association, Energy Storage in the UK An Overview 2 nd Edition, (2016). www.r-e-a.net.

[3] S. Koohi-Fayegh, M.A. Rosen, A review of energy storage types, applications and recent developments, J. Energy Storage. (2020). https://doi.org/10.1016/j.est.2019.101047.

[4] M. Winfield, S. Shokrzadeh, A. Jones, Energy policy regime change and advanced energy storage: A comparative analysis, Energy Policy. 115 (2018) 572-583. https://doi.org/10.1016/j.enpol.2018.01.029.

[5] M. Di Castelnuovo, M. Vazquez, Policy and Regulation for Energy Storage Systems, 2018. www.iefe.unibocconi.it.

[6] B. Jo, S. Jung, G. Jang, Feasibility Analysis of Behind-the-Meter Energy Storage System According to Public Policy on an Electricity Charge Discount Program, Sustainability. (2019). https://doi.org/10.3390/su11010186.

[7] D.B. et Al., MARKET AND POLICY BARRIERS TO ENERGY STORAGE A Study for the Energy Storage Systems Program, 2013. http://www.sandia.gov/ess/publications/SAND2013-7606.pdf.

[8] K.K. Zame, C.A. Brehm, A.T. Nitica, C.L. Richard, D.S. Iii, Smart grid and energy storage: Policy recommendations, Renew. Sustain. Energy Rev. (2017) 1-9. https://doi.org/10.1016/j.rser.2017.07.011.

[9] T.S. Schmidt, J. Huenteler, Anticipating industry localization effects of clean technology deployment policies in developing countries, Glob. Environ. Chang. $38 \quad$ (2016) 8-20. https://doi.org/10.1016/j.gloenvcha.2016.02.005.

[10] J. Cramer, Energy Storage State Policy Update, CELA Webinar, Energy Storage Association, (n.d.). http://cnee.colostate.edu/wp-content/ uploads/2017/07/ Cramer_LatestEnergyStorage.pdf (accessed March 8, 2019).

[11] S. I. Lee et al, Plans for Energy Storage Systems Market Creation (Korea), 2015.

[12] American Energy Innovation Act, (n.d.). https://energystorage.org/legislative-summary/american-energyinnovation-act-would-elevate-energy-storage-to-a-top-rdd-priority/ (accessed April 15, 2020).

[13] Energy Storage Association, Energy storage in Rural Communities, (n.d.). https://energystorage.org/legislative-summary/farm-bill-opens-opportunities-for-energy-storage-in-ruralenergy-programs/\%0A\%0A (accessed April 15, 2020).

[14] A. Zablocki, Fact Sheet: Energy Storage US, (2019). https://www.eesi.org/papers/view/energy-storage-2019 (accessed April 15, 2020).

[15] S.3159 - Energy Storage Tax Incentive and Deployment Act of 2016, (2016). https://www.congress.gov/bill/114th-congress/senate-bill/3159 (accessed April 2, 2020).

[16] Congressional Research Service, S. 3159 (114th): Energy Storage Tax Incentive and Deployment Act of 2016, (n.d.). https://www.govtrack.us/congress/bills/114/s3159/summary (accessed April 20, 2020).

[17] Heinrich Introduces Bipartisan Bill To Create Tax Credit For Energy Storage, (n.d.). https://www.heinrich.senate.gov/press-releases/heinrich-introduces-bipartisan-bill-to-create-tax-credit-forenergy-storage (accessed April 20, 2020).

[18] United States Senate Committee on Energy \& Natural Resources, Summary of the Storage Technology for 
Renewable and Green Energy Act of 2013, or the "STORAGE 2013 Act," 2013. http://www.energy.senate.gov/public/index.cfm/files/serve?File_id=9d8db575-\%0A89ed-44ef-97a7$52 \mathrm{e} 8 \mathrm{a} 6 \mathrm{bd} 1 \mathrm{bae}$.

[19] E. Wesoff, FERC's Energy Storage Ruling Could Jump-Start Big Batteries, (2013). https://www.greentechmedia.com/articles/read/FERCs-Energy-Storage-Ruling-Could-Jump-Start-BigBatteries (accessed April 10, 2020).

[20] Federal Energy Regulatory Commission, FERC Order 841, 2018. https://www.ferc.gov/whats-new/commmeet/2018/021518/E-1.pdf.

[21] D.M. Hart, W.B. Bonvillian, N. Austin, Energy Storage for the Grid: Policy Options for Sustaining Innovation, An MIT Energy Initiat. Work. Pap. 1 (2018) 33. https://energy.mit.edu/wp-content/uploads/2018/04/EnergyStorage-for-the-Grid.pdf.

[22] J. Twitchell, A Review of State-Level Policies on Electrical Energy Storage, Curr. Sustain. Energy Reports. 6 (2019) 35-41. https://doi.org/10.1007/s40518-019-00128-1.

[23] Hawaii Electric, Power Supply Improvement Plan, (n.d.). https://www.hawaiianelectric.com/clean-energyhawaii/integrated-grid-planning/power-supply-improvement-plan (accessed April 25, 2020).

[24] P. Maloney, Oregon PUC release guidelines for energy storage mandate, (n.d.). https://www.utilitydive.com/news/oregon-puc-release-guidelines-for-energy-storage-mandate/433462/ (accessed March 10, 2020).

[25] National Association of Regulatory Utility Commissioners, Commissioner Tobin Proposes Comprehensive Energy Reform, (2018). https://www.naruc.org/bulletin/the-bulletin-02-07-2018/state-news/commissionertobin-proposes-comprehensive-energy-reform/ (accessed March 10, 2020).

[26] A. Colthorpe, Global leader' California's main utilities given additional 500MW energy storage procurement target, (2017). https://www.energy-storage.news/news/global-leader-californias-main-utilities-givenadditional-500mw-energy-stor (accessed April 2, 2020).

[27] Public Service Commission New York, CASE 18-E-0130 ORDER ESTABLISHING ENERGY STORAGE GOAL AND DEPLOYMENT POLICY, 2018. https://doi.org/10.4159/harvard.9780674287877.c3.

[28] H.H. Kathleen Burgess, J.B. Rhodes, G.C. Sayre Diane X Burman James S Alesi, New York State Energy Storage Roadmap and Department of Public Service / New York State Energy Research and Development Authority Staff Recommendations 2, (2018). www.dps.ny.gov.

[29] New Jersey, D. of C. Affairs, Renewable Energy Incentive Program (REIP) Fiscal Year 2015 Renewable Electric Storage Incentive, 2014.

[30] Office of Clean Energy New Jersey Board of Public Utilities, Solicitation Renewable Energy Incentive Program ( REIP ) Fiscal Year 2015 Renewable Electric Storage Incentive, 2014.

[31] Pacific Northwest National Lab, Energy Storage Policy Database, (n.d.). https://energystorage.pnnl.gov/regulatoryactivities.asp (accessed April 15, 2020).

[32] S.L. and G.M. Xavier Potau, Battery Promoting Policies in Selected Member States Batstorm work package 5 Battery Promoting Policies in Selected Member States Batstorm work package 5, (2018).

[33] Ofgem, Clarifying the regulatory framework for electricity storage: Statutory Consultation on electricity generation licence changes and next steps, (2019) 1-12. https://www.ofgem.gov.uk/publications-andupdates/clarifying-regulatory-framework-electricity-storage-statutory-consultation-proposed-modificationselectricity-generation-licence.

[34] UK power networks, The Smarter Network Storage (SNS), (n.d.). http://innovation.ukpowernetworks.co.uk/innovation/en/Projects/tier-2-projects/Smarter-Network-Storage (accessed April 1, 2020).

[35] Green Growth, Cumbria Large scale Battery, (2017). https://www.green-growth.org.uk/article/cumbria-set- 
large-scale-battery-storage-facility (accessed April 10, 2020).

[36] AES Energy Storage, UK's Biggest Battery Energy Storage System, (n.d.). http://aesenergystorage.com/2016/01/07/aes-announces-completion-of-the-uks-biggest-battery-energystorage-array (accessed April 1, 2020).

[37] National Grid UK, Enhanced frequency response, (n.d.). http://www2.nationalgrid.com/Enhanced-FrequencyResponse.aspx), (accessed March 27, 2020).

[38] Energy Saving Trust, Domestic charge point funding, (n.d.). http://www.energysavingtrust.org.uk/scotland/grants-loans/domestic-charge-point-funding (accessed April 1, 2020).

[39] International Energy Agency, Subsidy for solar PV with storage installations (Programm zur Förderung von PV-Batteriespeichern), (2016). https://www.iea.org/policies/5971-subsidy-for-solar-pv-with-storageinstallations-programm-zur-forderung-von-pv-

batteriespeichern?country=Germany\&technology=Solar\%2CWind\%2CMultiple renewable technologies\%2CTransport technologies\&topic=Energy Efficiency\%2C (accessed March 23, 2020).

[40] K.P. Kairies, J. Figgener, D. Haberschusz, O. Wessels, B. Tepe, D.U. Sauer, Market and technology development of PV home storage systems in Germany, J. Energy Storage. 23 (2019) 416-424. https://doi.org/10.1016/j.est.2019.02.023.

[41] Federal Ministry of Justice and Consumer Protection (Germany), Law for the development of renewable energy sources, (2014). https://www.gesetze-im-internet.de/eeg_2014/BJNR106610014.html (accessed April 5, 2020).

[42] Red Electrica de Espana (REE.ES), Almacena Project, (n.d.). https://www.ree.es/en/sustainability/noteworthyprojects/rdi-projects-that-contribute-to-the-business/almacena-project (accessed April 10, 2020).

[43] I. Lammers, L. Diestelmeier, Experimenting with law and governance for decentralized electricity systems: Adjusting regulation to reality?, Sustain. 9 (2017). https://doi.org/10.3390/su9020212.

[44] Norton Rose Fulbright, Energy storage updater - June 2019, (2019). https://www.nortonrosefulbright.com/enfr/knowledge/publications/dc63e6f0/energy-storage-updater-june-2019 (accessed April 10, 2020).

[45] H. Hirabayashi, T., Furuta, S., \& Satoh, Status of the Moonlight Project on advanced battery electric energy storage system. United States: American Nuclear Society, Boston, 1991.

[46] M. Berre, The Energy Storage Landscape in Japan, 2016. www.EUbusinessinJapan.eu\%0A.

[47] New Energy and Industrial Technology Development Organization, (n.d.). https://www.nedo.go.jp/english/introducing_index.html (accessed April 10, 2020).

[48] C. Watanabe, A View from Japan's Challenge: The New Sunshine Program, Renew. Energy. 6 (1995) $237-$ 274.

[49] JFS, METI Establishes Project Team to Promote Storage Battery Industry, (2012). https://www.japanfs.org/en/news/archives/news_id031735.html (accessed March 27, 2020).

[50] METI, 4th Strategic 2014. https://www.enecho.meti.go.jp/en/category/others/basic_plan/pdf/4th_strategic_energy_plan.pdf.

[51] J.B. Kucharski, H. Unesaki, Japan 's 2014 Strategic Energy Plan : A Planned Energy System Transition, 2017 (2017).

[52] T. Tomita, Policies and Regulations for Electricity Storage in Japan, in: Düsseldorf, Germany, 2014.

[53] F. Yang, X. Zhao, Policies and economic efficiency of China's distributed photovoltaic and energy storage industry, Energy. 154 (2018) 221-230. https://doi.org/10.1016/j.energy.2018.04.135.

[54] Y. Xiao, Y. Gao, S. Kuang, K. Sun, L. Yang, J. Hu, B. Wang, Comparative Analysis on Energy Storage Policies at Home and Abroad and Its Enlightenment, IOP Conf. Ser. Earth Environ. Sci. 267 (2019). 
https://doi.org/10.1088/1755-1315/267/3/032019.

[55] China Chamber of Commerce for Import and Export of Textile and Apparel, Renewable Energy Law of the People's Republic of China, (n.d.). http://www.ccct.org.cn/Pub/S/4301/205585.shtml (accessed February 15, 2020).

[56] National Development and Reform Commission, Reference material for the Fourth Session of the Tenth National People's Congress, https://en.ndrc.gov.cn/newsrelease_8232/200603/t20060313_1193873.html (accessed March 15, 2020).

[57] The State Council of The PRC, The National Medium-and Long-Term Program for Science and Technology Development (2006- 2020) II. Guiding Principles, Development Goals, and Overall Deployment 1 . Guiding Principles 2. Development Objectives 3. Overall Deployment III. Main Areas and Prior, (2006). https://www.itu.int/en/ITU-D/Cybersecurity/Documents/National_Strategies_Repository/China_2006.pdf.

[58] M. Fulton, 12 th Five Year Plan - Chinese Leadership Towards A Low Carbon Economy, Middle East. (2011) 1-16. https://www.dbadvisors.com/content/_media/China_12th_Five_Year_Plan.pdf.

[59] Xinhua News Agency, Twelfth five-year plan for national economic and social development of the People's Republic of China, (2011). http://www.gov.cn/ 2011lh/content_1825838.html (accessed March 10, 2020).

[60] National Energy Administeration, Notice on formulating the thirteenth five-year plan for the development of solar energy, (2014). http://zfxxgk.nea.gov.cn/auto87/201412/t20141224_1872.htm.

[61] National Energy Agency, Guiding opinions on implementing the demonstration projects on new energy microgrids, (2015). http://zfxxgk.nea.gov.cn/auto87/201507/ t20150722_1949.htm\%22 (accessed March 10, 2020).

[62] T.S. Council, Several opinions on further deepening the Reform of the electric power system, (2015). http://tgs.ndrc.gov.cn/zywj/201601/t20160129_773852.html (accessed March 10, 2020).

[63] Central Committee of the Communist Party of China, The 13th Five-Year Plan For Economic And Social Development of the People's Republic of China, 2020.

[64] National Development and Reform Commission, Notice on the publication of the 13th Five Year Plan for the development of renewable energy, 2016. http://zfxxgk.ndrc.gov.cn/PublicItemView.aspx?ItemID=\%7Bcabb8fde-2380-4807-b0fe-0f4b8c259c30\%7D.

[65] National Development and Reform Commission, Ministry of Industry and Information Technology, Ministry of Environmental Protection, Ministry of Commerce, General Administration of Quality Inspection. Notice on releasing the measures of technical policy for the recycling and utilization of power st, (2016). http://www.ndrc.gov.cn/zcfb/zcfbgg/201601/ t20160128_773250.html (accessed March 12, 2020).

[66] National Development and Reform Commission and National Energy Agency, Notice on releasing the thirteenth five-year plan for energy development., (2016). http://www.sdpc.gov.cn/zcfb/zcfbtz/201612/t20161216_830264.html (accessed March 12, 2020).

[67] Ministry of Trade Industry and Energy (MOTIE), Customised Electric rates systems for ESS and EV industries, (n.d.). http://english.motie.go.kr/en/tp/alltopics/bbs/bbsView.do?bbs_cd_n=3\&bbs_seq_n=21 (accessed April 2, 2020).

[68] Australian Renewable Energy Agency, (n.d.). https://arena.gov.au/about/ (accessed April 1, 2020).

[69] Clean Energy Council, Clean Energy Australia Report 2020, 2020. https://assets.cleanenergycouncil.org.au/documents/resources/reports/clean-energy-australia/clean-energyaustralia-report-2020.pdf.

[70] H. Britton, South Australia Low Carbon Investment, 2015. https://www.hawkerbritton.com/2015/12/southaustralia-low-carbon-investment-plan/.

[71] S.C. Staff, How the South Australian government is supporting renewables \& energy storage, (2016). https://www.solarchoice.net.au/blog/news/how-south-australian-government-supporting-renewables-energy- 
storage-290316 (accessed April 3, 2020).

[72] Home Battery Scheme, South Australia's Home Battery Scheme, (2020). https://homebatteryscheme.sa.gov.au/about-the-scheme (accessed August 15, 2020).

[73] Hornsdale Power Reserve, South Australia’s Biggest Battery, (n.d.). https://hornsdalepowerreserve.com.au (accessed August 15, 2020).

[74] ACT Sustainable Energy Policy Energy for a sustainable city, 2011. http://www.environment.act.gov.au/energy/energy_policy.

[75] Environment Planning and Sustainable Development Directorate, Next Generation Energy Storage (Next Gen) Program, (n.d.). https://www.environment.act.gov.au/energy/cleaner-energy/next-generation-renewables (accessed April 3, 2020).

[76] Environment Planning and Sustainable Development Directorate, Growth in the Clean Economy, (n.d.). https://www.environment.act.gov.au/energy/growth-in-the-clean-economy (accessed April 3, 2020).

[77] Clean Energy Council, Charging Forward : Policy and Regulatory Reforms To Unlock the Potential of Energy Storage in Australia Clean Energy Council Briefing Paper, 2017. https://assets.cleanenergycouncil.org.au/documents/resources/reports/unlocking-energy-storage-inaustralia.pdf.

[78] A.S. Sidhu, M.G. Pollitt, K.L. Anaya, A social cost benefit analysis of grid-scale electrical energy storage projects: A case study, Appl. Energy. 212 (2018) 881-894. https://doi.org/10.1016/j.apenergy.2017.12.085.

[79] K. Bradbury, L. Pratson, D. Patiño-Echeverri, Economic viability of energy storage systems based on price arbitrage potential in real-time U.S. electricity markets, Appl. Energy. 114 (2014) 512-519. https://doi.org/10.1016/j.apenergy.2013.10.010.

[80] Energy Storage Association, Benefits of Energy Storage, (n.d.). https://energystorage.org/why-energystorage/benefits/ (accessed March 15, 2020).

[81] International Energy Agency (IEA), Energy Storage, (2020). https://www.iea.org/reports/energy-storage (accessed August 17, 2020).

[82] M. Arbabzadeh, J.X. Johnson, G.A. Keoleian, P.G. Rasmussen, L.T. Thompson, Twelve Principles for Green Energy Storage in Grid Applications, Environ. Sci. Technol. 50 (2016) 1046-1055. https://doi.org/10.1021/acs.est.5b03867.

[83] F.J. de Sisternes, J.D. Jenkins, A. Botterud, The value of energy storage in decarbonizing the electricity sector, Appl. Energy. 175 (2016) 368-379. https://doi.org/10.1016/j.apenergy.2016.05.014.

[84] International Energy Agency, Global Energy Review 2020, 2020. https://www.iea.org/reports/global-energyreview-2020.

[85] N. Khan, S. Dilshad, R. Khalid, A.R. Kalair, N. Abas, Review of energy storage and transportation of energy, Energy Storage. 1 (2019) 1-49. https://doi.org/10.1002/est2.49.

[86] M. Engelken, B. Römer, M. Drescher, I.M. Welpe, A. Picot, Comparing drivers, barriers, and opportunities of business models for renewable energies: A review, Renew. Sustain. Energy Rev. 60 (2016) 795-809. https://doi.org/10.1016/j.rser.2015.12.163.

[87] M. Suzuki, Identifying roles of international institutions in clean energy technology innovation and diffusion in the developing countries: Matching barriers with roles of the institutions, J. Clean. Prod. 98 (2015) 229-240. https://doi.org/10.1016/j.jclepro.2014.08.070.

[88] World Energy Council, Energy Storage Monitor. Latest Trends In Energy Storage, 2019.

[89] D. Parra, M. Swierczynski, D.I. Stroe, S.A. Norman, A. Abdon, J. Worlitschek, T. O’Doherty, L. Rodrigues, M. Gillott, X. Zhang, C. Bauer, M.K. Patel, An interdisciplinary review of energy storage for communities: Challenges and perspectives, Renew. Sustain. Energy Rev. 79 (2017) 730-749. 
https://doi.org/10.1016/j.rser.2017.05.003.

[90] R. Puliti, M.D. Bazilian, How a Key Energy Technology Can Help Developing Countries, (2019). https://blogs.scientificamerican.com/observations/how-a-key-energy-technology-can-help-developingcountries/ (accessed May 1, 2020).

[91] Power Technology, The world's most used renewable power sources, (2020). https://www.powertechnology.com/features/featurethe-worlds-most-used-renewable-power-sources-4160168/) (accessed August 17, 2020).

[92] C.S. Lai, Y. Jia, L.L. Lai, Z. Xu, M.D. McCulloch, K.P. Wong, A comprehensive review on large-scale photovoltaic system with applications of electrical energy storage, Renew. Sustain. Energy Rev. 78 (2017) 439-451. https://doi.org/10.1016/j.rser.2017.04.078.

[93] Y. Wu, L. Zhang, Can the development of electric vehicles reduce the emission of air pollutants and greenhouse gases in developing countries?, Transp. Res. Part D Transp. Environ. 51 (2017) 129-145. https://doi.org/10.1016/j.trd.2016.12.007.

[94] R. Singh, Commercial Viability of Solar Power Projects, SSRN Electron. J. (2018). https://doi.org/10.2139/ssrn.3219941.

[95] The Office of Energy Efficiency and Renewable Energy, Reducing Pollution with Electric Vehicles, (n.d.). https://www.energy.gov/eere/electricvehicles/reducing-pollution-electric-vehicles (accessed May 15, 2020).

[96] A. Eller, D. Gauntlett, Energy storage trends and opportunities in emerging markets, 2017. https://www.ifc.org/wps/wcm/connect/ed6f9f7f-f197-4915-8ab6-56b92d50865d/7151-IFC-EnergyStoragereport.pdf?MOD=AJPERES\%0Ahttp://prism.talis.com/sussexac/items/1112426\%5Cnhttp://suss.eblib.com/patron/FullRecord.aspx?p=588991\%0Ahttps://www.ifc.org/wps $/ \mathrm{wcm} /$.

[97] X. SUN, Solar Technology Got Cheaper and Better in the 2010s. Now What?, (2019). https://www.greentechmedia.com/articles/read/solar-pv-has-become-cheaper-and-better-in-the-2010s-nowwhat (accessed April 28, 2020).

[98] Energy Storage Association, End-of-Life Management of Lithium-ion Energy Storage Systems, 2020.

[99] A. Mayyas, D. Steward, M. Mann, The case for recycling: Overview and challenges in the material supply chain for automotive li-ion batteries, Sustain. Mater. Technol. $19 \quad$ (2019) e00087. https://doi.org/10.1016/j.susmat.2018.e00087. 